\title{
Asesmen Perkembangan Sosial Emosional Anak Usia Dini
}

\author{
Yuwita Dabis, Yenti Juniarti \\ Jurusan PG-PAUD Universitas Negeri Gorontalo \\ yenti.juniarti@gmail.com
}

\section{Info Artikel}

Sejarah Artikel:

Diterima (April) (2019)

Disetujui (Mei) (2019)

Dipublikasikan (Juli) (2019)

Keywords:

Asessment, Emotional social development, Early Childhood

\begin{abstract}
Abstrak
Asesmen perkembangan merupakan upaya yang dilakukan untuk menganalisis data yang terkait dengan perkembangan suatu aspek yang dilalui anak. Penelitian ini dilatar belakngi bagaimana mengasesmen pencapaian perkembangan sosial emosional anak. Tujuan penelitian ini untuk mengetahui bagaimana peran guru dalam mengasesmen perkembangan sosial emosioanl serta bagaimana cara meningkatkan perkembangan sosial emosional pada anak. Adapun metode yang digunakan dalam penelitian ini yaitu metode kualitatif dengan prosedur tahap pralapngan, kegiatan lapangan dan analisa data. Hasil penelitian ini menunjukan bahwa perkembangan sosial emosional setiap anak berbeda-beda. Ada anak yang sudah mampu berinteraksi dengan lingkungan dan mampu mengendalikan emosionalnya. Namun, ada pula anak yang masih belum mampu yaitu dapat dilihat dari kurangnya percaya diri anak dan sikap anak yang masih memiliki ego yang cukup tingi. Kesimpulan dari penelitian ini yaitu perkembangan sosial emosional di TK PGRI Beringin Mardia sangat bervariasi. sehingga perlu adanya program guru untuk mengasesmen setiap perkembangan sosial emosional anak yang terjadi setiap harinya.
\end{abstract}

\begin{abstract}
Developmental assessment is an effort made to analyze data related to the development of an aspect through which the child passes. This research is motivated by how to assess the achievement of children's social emotional development. The method used in this study is a qualitative method with prefield stage procedures, field activities and data analysis. The results of this study indicate that each child's emotional social development is different. There are children who are able to interact with the environment and are able to control their emotions. However, there are also children who are still unable, which can be seen from the lack of self confidence and the attitude of children who still have quite high selfishness. The conclusion of this study is that the social emotional development in TK Beringin Mardia varies greatly. so there is a need for a teacher program to assess every child's social emotional development that happens every day.
\end{abstract}

(c) 2019 Yuwita Dabis, Yenti Juniarti Under the license CC BY-SA 4.0

\section{Pendahuluan}

Sebagaimana disebutkan dalam Undang-undang sisdiknas bahwa pendidikan merupakan suatu usaha sadar terencana untuk mewujudkan suasana belajar dan proses 
pembelajaran agar peserta didik secara aktif mengembangkan potensi dirinya untuk memiliki spiritual keagamaan, pengendalian diri, kepribadian, kecerdasan akhlak mulia, serta keterampilan yang diperlukan dirinya, masyarakat, bangsa, dan Negara. Mengacu pada definisi ini menunjukan bahwa pendidikan sangat penting dan berguna bagi kemajuan dan perkembangan peserta didik.

Asesmen merupakan suatu penerapan dan pengunaan berbagai cara dan alat untuk mendapatkan serangkaian informasi tentang hasil belajar dan pencapaian kompetensi dari peserta didik. Sejalan dengan itu, asesmen pendidikan anak usia dini merupakan suatu proses kegiatan yang dilaksanakan bertujuan mengumpulkan data atau bukti-bukti tentang perkembangan dan hasil belajar yang berkaitan dengan perkembangan anak usia dini. (Yuliani, 2009).

Penilaian dalam konteks pembelajaran di pendidikan anak usia dini (PAUD) merupakan proses pengumpulan dan pengolahan informasi untuk menentukan tingkat pencapaian perkembangan anak dan pengambilan keputusan, pengakuan atau ketetapan tentang kondisi (kemampuan anak). Kegiatan ini dilaksanakan dengan mengunakan berbagai metode dan instrument yang relevan. Penilaianan itu sendiri yaitu bertujuan untuk merencanakan pembelajaran individual dan kelompok agar dapat berkomunikasi dengan orang tua, mengetahui dan menindak lanjuti pertumbuhan dan perkembangan yang telah dicapai anak selama mengikuti pendidikan. Perilaku sosial adalah perilaku sukarela yang memberikan manfaat kepada orang lain. Kemampuan berperilaku sosial ini perlu dimiliki sejak usia dini mengingat sebagai suatu pondasi bagi perkembangan kemampuan anak berinteraksi dengan lingkungannya secara lebih luas. Oleh karena itu, perilaku sosial pada anak usia dini dapat dibentuk sejak pertama kali pada lingkungan kelompok sosial yang paling sederhana yaitu di lingkungan keluarga.

Perkembangan sosial emosional pada anak-anak yaitu kemampuan untuk berinteraksi serta memberikan respon terhadap sesuatu dan bertingkah laku mengikuti norma masyarakat. Perkembangan ini berjalan sesuai dengan tahap-tahap perkembangan anak. Perkembangan sosial emosional adalah salah satu dominan perkembangan yang sangat penting bagi anak-anak tanpa melihat ketidakmampuannya. (Hayati dkk, 2014). Dalam konteks ini perkembangan sosial meliputi dua aspek penting, yaitu kompetensi dan tangung jawab sosial. Kompetensi sosial yaitu mengambarkan 
kemampuan anak untuk beradaptasi dengan lingkungan sosialnya secara efektif. Misalnya, ketika temannya menginginkan sesuatu, ia mau bergantian. Sementara tangung jawab sosial yaitu antara lain ditunjukan oleh komitmen anak terhadap tugastugasnya, menghargai perbedaan individual, dan memperhatikan apa yang ada dilingkungannya. Sedangkan pada umumnya anak kecil lebih emosional dari pada orang dewasa karena pada usia ini anak masih relative muda dan belum dapat mengendalikan emosinya. Ekspresi pada anak mudah berubah dengan cepat dari satu bentuk ekspresi kebentuk ekspresi emosi yang lain. Rangsangan yang sering membangkitkan emosi anak adalah keinginan yang tidak terpenuhi, dengn cara mengungkapkan ekspresi yang tidak terkendali.

Berdasarkan hasil penelitian yang dilakukan di TK PGRI Beringin Mardia Tanoyan Utara, menunjukan bahwa ada sebagian anak yang mengalami kendala dalam perkembangan sosial emosional. Dimana ada ada anak yang belum bisa berinteraksi dengan teman sebayanya, belum bisa mengendalikan sikap emosionalnya dengan baik. Sehingganya anak-anak memiliki kesulitan dalam mengikuti segala aturan-aturan yang diberikan guru. Akan tetapi di sisi lain ada anak yang sangat terampil dan perkembangan sosial emosionalnya denga menujukan rasa percaya diri dan mampu untuk mengendalikan emosionalnya denagn baik.

Kemudian dalam hal ini, untuk mengembangkan kemampuan anak dalam aspek sosial emosional guru dapat melakukan metode atau tekhnik serta membuat suatu rancangan yang terstruktur sehinganya dapat mengasah keterampilan soisial emosional anak usia dini. Selain itu guru dapat mengasahnya dengan mengunakan permaiananpermaianan yang kreatif, menarik serta edukatif yang berhubungan dengan pengembangan keterampilan dalam aspek sosial emosional.

Tujuan dari peneletian ini yaitu untuk mengetahui bagaimana meningkatkan perkembangan sosial emosional anak. serta bagaimana cara guru mengasesmen perkembangan sosial emosioanl anak dengan melihat pola tingkah laku anak di lingkungan sekolah. Kematangan emosi seorang anak merupakan kunci dari sebuah keberhasilan dalam menjalin suatu hubungan sosialnya, kecakapan tersebut merupakan faktor utama dalam menunjang keberhasilan pada pergaulan. Salah satu kunci kecakapan sosial adalah seberapa baik atau buruknya seseorang mengungkapkan perasaannya. (Goelman, 2006) 


\section{Metode Penelitian}

Jenis Penelitian

Dalam penelitian ini peneliti mengunakan pendekatan kualitatif. Pendekatan kualitatif merupakan metode peneletian yang bersifat deskriptif atau metode yang mendeskrpsikan suatu permasalahan dari hasil analisa di lapangan. Sebagaimana menurut (Moleong, 2005) metode penelitian kualitatif adalah suatu riset yang bermaksud untuk memahami fenomena yang dialami oleh subjek peneliti. Misalnya perilaku, persepsi, motivasi, tindakan, dan lain-lain, secara holistic, dan dengan cara deskripsi dalam bentuk kata-kata dan bahsa pada suatu konteks khusus yang alamiah. Metode kualitatif ini sangat sejalan dengan penelitian ini dimana peneliti melihat fakta dilapangan kemudian menganalisa berbagai permasalahan yang ada dan selanjutnya di tuangkan dalam bentuk deskrpsi atau mendeskrpisikan hasil analisa tersebut.

Waktu dan Tempat Penelitian

Penelitian ini dilakukan pada bulan Oktober sampai bulan November di TK PGRI Beringin Mardia yang beralamatkan di desa Tanoyan Utara, Kec.Lolayan, Kab.Bolaang Mongondow, Sulawesi Utara.

Subjek Penelitian

Subjek penelitian yaitu anak-anak di TK PGRI Beringin Mardia. Dengan jumlah Anak Perempuan 12 orang dan anak laki-laki 10 orang.

Tahap pralapangan

Tahap pralapangan merupakan kegiatan yang dilakukan peneliti sebelum pengumpulan data. Adapun kegiatan-kegiata pada tahap pralapngan ini yaitu menyusun rancangan penelitian, memilih lapangan focus penelitian, menjajaki dan menilai keadaan lapangan, dan menyiapkan perlengakapan penelitian.

Tahap kegiatan lapangan

Tahap ini merupakan kegiatan peneliti yang dilakukan langsung di tempat penelitian. Pada tahap ini kegiatan terbagi menjadi 3 yaitu memahami latar penelitian dan persiapan diri, memasuki lapangan penelitian, dan berperan serta sambil mengumpulkan data. 
Tahap analisa data

Terdapat beberapa prinsip pokok dalam anlisa data, prinsip tersebut meliputi konsep dasar, menemukan tema dan merumuskan hipotesis, serta bekerja dengan hipotesis.

Teknik Analisis Data

Dalam menganalisa data, peneliti mengunakan teknik dengan mengunakan metode berupa deskriptif yaitu dengan melihat data-data dari hasil penelitian dilapangan. Pada dasarnya analisa data dengan mengunakan metode kualitatif yaitu dapat dilakukan bersamaan dengan proses pengumpulan data selama dilapangan. Sebagaimana yang dikemukakan oleh (Barsowi dan Suwandi, 2008) aktivitas dalam analisis data mencakup tiga kegiatan yang bersamaan yaitu diantaranya redukasi, penyajian data dan penarikan kesimpulan.

\section{Hasil Penelitian dan Diskusi}

Berdasarkan hasil penelitian yang dilakukan, menunjukan bahwa perkembangan sosial emosional anak-anak di TK PGRI Beringin Mardia sangat bervariatif. Setiap anak memiliki perkembangan sosial emosional yang berbeda-beda. Ada anak yang sudah mampu dalam berinteraksi dengan lingkungan sekolah dan bisa mengontrol emosinya. Namun, ada pula anak yang masih kurang mampu atau masih perlu adanya pengawasan guru dalam berinteraksi dengan lingkungan sekolah. Hal ini berkenaan dengan penelitian sebelumnya yaitu, anak mengalami kendala dalam belajarnya yang berasal dari dalam diri karena keterampilan sosial emosional mereka masih kurang. Kurangnya keterampilan sosial emosional ini terlihat dari kurangnya kesadaran anak untuk mengembangkan kemampuan yang dimilikinya, kurangnya empati atau bersifat mengikut dan kurang bekerja sama dengan orang lain, dengan teman-teman lain, tidak mampu untuk mengendalikan emosi sehingga menimbulkan kesulitan lain dalam diri anak untuk mengikuti aturan-aturan yang diberikan oleh guru. (Isbayani dkk, 2015)

Pada saat masuk di lingkungan sekolah anak-anak memberikan salam serta menyapa guru dan teman-teman disekolah. Sebagaimana yang dijelaskan bahwa perkembangan sosial merupakan proses belajar anak dalam menyesuaikan diri dengan norma, moral dan tradisi dalam sebuah kelompok. (Yusuf dan Yahro, 2009). 
Dalam berinteraksi sosial. Sebagian anak-anak mampu berinteraksi dengan teman-teman sebayanya. Namun pada anak A dan B masih kurang mampu untuk berinteraksi dengan teman-temannya, dapat dilihat dari tingkah laku anak di dalam kelas dimana anak hanya diam di tempat duduk sedangkan teman-teman yang lain bercerita dan sangat aktif di dalam kelas. Hal ini sejalan dengan yang dikemukakan oleh (Nurmalitasari, 2015) bahwa interaksi sosial membutuhkan keterampilan khusus yang didorong ole kondisi emosi anak seperti motivasi, empati, dan menyelesaikan konflik. Anak yang dapat mengendalikan diri dan mudah menunjukan empati dan kasih sayang akan mudah bersosialisasi dengan orang disekitarnya.

Anak mampu menunjukan sikap tolong menolong antar sesama teman. Hal ini dapat peneliti lihat pada saat di dalam kelas salah satu anak yang tidak memiliki pensil kemudian ia meminjam pensil ke temannya, dengan memberikan respon yang baik temannyapun segera memberikan pensil yang satunya kepas anak tersebut. Dengan begitu, stimulus yang diberikan guru secara optimal akan dapat membantu sikap dari diri seorang anak. Hal ini berkenaan dengan penelitian sebelumnya bahwa dengan adanya rangsangan kepada anak tentang menumbuhkan jiwa tolong menolong dan telah berhasil ditumbuhkan dalam diri mereka, asalkan anak dibiasakan untuk melakukan dan mencontoh hal-hal yang baik. (Fadjryana dan Ewi, 2015).

Adapun sikap dalam bekerja sama kelompok yaitu dari hasil pengamatan, peneliti dapat melihat bagaimana sikap anak dalam bekerja sama dengan teman kelompok dalam melakukan sebuah tugas yang diberikan guru. Tidak semua anak mampu untuk menyelasaikan tugas dengan melakukan bekerja sama yang baik. Namun ada juga anak yang sudah mampu bahkan sangat aktif dalam melakukan kerja sama untuk menyelsaikan sebuah tugas. Seperti yang terlihat pada anak B, C dan D yang kurang terampil dalam menunjukan kerja sama dalam kelompok untuk menyelasaikan tugas, sedangkan anak-anak yang lain sangat antusias memencakan atau menyelsaikan tugas yang diberikan guru. Hal ini berkenaan dengan penelitian sebelumnya yang dilakukan oleh (Nugrahaningtyas, 2014) bahwasannya ada anak yang menujukan sikap koperatif yang kurang baik. Sebagaimana bentuk kerja sama anak seperti melaksanakan tugas kelompok, saling membantu menjaga barang milik bersam tidak tampak. Dimana anak acuh dalam melakukan hal tersebut. Namun berbeda dengan anak yang lainnya yang sudah mampu menujukan sikap kooperatif yang cukup baik. Ketika melaksanakan 
tugas kelompok meraka sudah bisa atau sudah menampakan kerja samanya dalam menyelesaikan tugas kelompok. Hal tersebut sejalan denagan penjelasan yang dikemukakan oleh (Susanto, 2011) bahwa perkembangan sosial merupakan pencapaian kematangan dalam hubungan sosial. Dapat juga diartikan sebagai proses belajar untuk menyesuaikan diri terhadap norma-norma kelompok, moral dan tradisi, meleburkan diri menjadi satu kesatuan dan saling berkomunikasi, dan bekerja sama.

Selanjutnya dalam perkembangan emosional anak. Berdasarkan hasil pengamatan yang dilakukan peneliti. Anak-anak mampu mengendalikan emosinya, dapat dilihat dari bagaimana anak-anak bermain seluncuran dan ayunan. Dimana anakanak melakukannya secara bergiliran atau bergantian untuk bermain. Akan tetapi berbeda dengan anak $\mathrm{C}$ yang dengan keaktifannya sehingga ia tidak bisa mengendalikan emosinya dalam menungu giliran untuk bermain. Apabila kemaunnya itu tidak terpenuhi maka anak akan memberontak. Dengan begitu perlu adanya pengawasan dari guru untuk mengawasi kegiatan bermain anak. Perkembangan emosi pada diri seorang anak akan muncul manakala ia mengalami interaksi dengan lingkungan. Pada anak usia dini, ungkapan perasaan ini di tunjukan melalui berbagai respon yang dapat dilakukannya. Sejaalan dengan hal tersebut (Goleman, 1995) merumuskan emosi sebagai sesuatu yang merujuk pada suatu perasaan dan pikiran-pikiran khasnya, suatu keadaan biologis dan psikologis, serta serangkaian kecenderungan untuk bertindak.

Dalam mengendalikan rasa takut. Hampir semua anak memiliki keberanian yang bagus, merasa percaya diri, berani maju di depan kelas maupun berani untuk melakukan segala sesuatu permianan yang menantang. Namun berbeda dengan anak A ia masih belum bisa mengendalikan rasa takutnya bahkan apabila guru menyuruhnya untuk maju bernyayi di depan kelas ia hanya diam di tempat duduk masih kurangnya rasa percaya diri yang dia miliki. Akan tetapi apabila diberikan permainan yang cukup menantang anak A ini mampu menyelasikannya walaupun dalam waktu yang cukup lama karena masih membutukan waktu untuk saling berinteraksi yang baik dengannya. Hal ini sejalan dengan teori yang dijelaskan oleh (Yusuf, 2009) bahwa emosi timbul karena pengaruh jasmaniah atau kegiatan individu. Misalnya, menangis karena sedih, tertawa karena gembira, lari itu karena takut, dan berkelahi itu karena marah. 
Kemudian dalam penelitian selanjunya peneliti mengamati tentang bagaimana cara anak mengendalikan sikap emosionalnya dengan perasaan marah. Dimana terlihat pada anak $C$ yang apabila salah satu dari teman meminjam barang miliknya dia tidak meberikannya bahkan ia langsung menunjukan sikap emosionalnya dengan marah ataupun hingga menangis. Bahkan apabila ada temannya yang berusaha mengambil barangnya ia akan menujukan amarahnya sampai memukuli temanya tersbut. Hal ini jelas bahwa anak $\mathrm{C}$ belum dapat mengontrol atau mengendalikan emosinya pasa sutau situasi tertentu masih perlu adanya stimulus yang diberikan pendidik ataupun orang tua. Hal ini di dukung oleh taori yang dikemukakan (santrock, 2007) yang mendefinisikan emosi sebagai perasaan atau afeksi yang timbul ketikaseseorang berada dalam suatu keadaan yang dianggap penting oleh perilaku yang mengekspresikan kenyamanan atau ketidaknyamnan terhadap keadaan atau interaksi yang sedang dialami. Emosi dapat berupa bentuk rasa senang, takut, marah, dan sebagainya.

Pentingnya penilaian terhadap aspek perkembangan sosial emosional anak, yang tentunya guru dapat melakukannya dengan melihat setiap perilaku yang dilakukan anak. Penilaian dapat dilakukan dengan mengunakan alat ukur tingkat perkembanagan anak untuk membantu melihat bagaimana aspek perkembangan sosial emosional yang terjadi pada setiap anak. Guru harus lebih memberikan rangsangan atau stimulasi kepada anak yang masih kurang terampil dalam aspek sosial emosional baik itu dalam berinteraksi dengan lingkungan, maupun dalam mengontrol sikap emosional anak.

Sehubungan dengan penjelasan diatas, bahwasannya sebagai guru pendidikan anak usia dini, hendaknya mempersiapkan diri agar dapat memeberikan pengalaman yang berharga sesuai dengan kebutuhan anak. Guru harus berusaha mencari penyebab yang melatar belakangi setiap perilaku anak yang menyimpang, dan memahami latar belakang keluarga anak. Kemudian mencari solusi dan memberikan perhatian secara khusus kepada anak yang bersangkutan, dapat juga melibatkan anak untuk bermain dengan teman-temannya. Dalam pada itu, guru dapat memberikan tanggung jawab kepada anak-anak yang dapat memotivasi dan membangkitkan minat anak untuk bermain kemabli. Hal tersebut bisa juga dilakukan dengan kata-kata yang menyenagkan sehingga anak tertarik mengikuti kata-kata guru. Serta memberikan pujian ketika anak berhasil mengerjakan sesuatu. 


\section{Simpulan}

Dari uraian diatas dapat disimpulkan bahwa assesmen perkembangan merupakan suatu upaya penting yang dilakukan untuk menganalisis dan mengumpulkan data yang terkait dengan perkembangan tingkat pencapaian suatu aspek yang dilalui anak. perkembangan sosial emosional pada anak yaitu kemampuan anak untuk berinteraksi serta memberikan respon terhadap sesuatu dan bertingkah laku mengikuti norma masyarakat. Perkembangan sosial emosional adalah salah satu dominan perkembangan yang sangat penting bagi anak-anak tanpa melihat ketidakmampuannya.

Berdasarkan hasil penelitian yang dilakukan di TK PGRI Beringin Mardia, perkembangan sosial emosional anak sangat bervariatif dan berbeda-beda. Ada anak yang sudah memiliki perkembangan sosial emosional yang baik, dapat dilihat dari cara anak menunjukan perilakunya seperti cara anak berinteraksi dengan lingkungan sekolahnya dan cara anak untuk mengontrol emosinya. Adapula anak yang masih kurang dalam perkembangan sosial emosionalnya, yaitu ketika anak

\section{Daftar Pustaka}

Isbayani, S.N Dkk. (2015) Penerapan Metode Outbound Untuk Meningkatkan Ketrampilan Sosial Emosional Anak. Vol.3 No.(1)

Marlisa. (2012). Penggunaan Metode Bercerita Dalam Meningkatkan Aspek Perkembangan Anak Usia Dini. Universitas Pendidikan Indonesia.

Martani W. (2012). Metode Stimulasi dan Perkembangan Emosi Anak Usia Dini. Vol.39 No.(1). 112-120

Mulyasa, H.E (2012). Manajemen PAUD. Rosdakarya. Indonesia

Novianti R, Dkk. (2014). PemetaanKemampuan Guru PAUD Dalam Melaksanakna Asesmen Perkembangan Anak Usia Dini Di Kota Pekanbar. Vol.8 No.(1). 1 - 104

Nugrahaningtyas D.R. (2014) Perkembangan Sosial Emosional Anak Usia 4 - 6 Tahun Di Panti Asuhan Benih Kasih Kabupaten Sragen. Vol.3 No. (2)

Nurmalitasari, F. (2015). Perkembangan Sosial Emosional Pada Anak Usia Din., 23 (2) 103-111.

Suyadi. (2016). Teori Pembelajaran Anak Usia Dini. Remaja Rosdakarya

Suyadi, Ulfah. (2015). Konsep Dasar PAUD. PT Remaja Rosdakarya. Bandung 
JAMBURA Early Childhood Education Journal, Vol. ( 1) (2), (Juli) (2019), (Halaman)(37-45)|

Wahyudin, UH, Agustin M. (2014) Penilaian Perkembangan Anak Usia Dini. Refika Aditama 